\title{
Serum amyloid A protein in acute viral infections
}

Hiroyuki Miwata, Toshiyuki Yamada, Masahiko Okada, Toyoichiro Kudo, Hiroshi Kimura, Tsuneo Morishima
Department of

Paediatrics,

Nagoya University

School of Medicine,

Nagoya,

Japan

Hiroyuki Miwata

Toyoichiro Kudo

Hiroshi Kimura

Tsuneo Morishima

Department of

Laboratory Medicine,

Niigata University

School of Medicine,

Niigata,

Japan

Toshiyuki Yamada

Masahiko Okada

Correspondence and reprint requests to:

Dr Hiroyuki Miwata,

Departm int of Paediatrics,

Nagoya University School

of Medicine,

65 Tsuruma-cho,

65 Tsurum

Nhowa-ku,

Japan.

Accepted 10 September 1992

\begin{abstract}
Concentrations of serum amyloid A protein (SAA) were measured in 254 children with viral diseases, including measles, varicella, rubella, mumps, echo-30 meningitis, chronic hepatitis B and C, and in eight with Kawasaki disease.
\end{abstract}

Latex agglutination nephelometric immunoasay was used for assaying SAA. In 191 out of 195 patients (98\%), SAA concentrations became markedly raised in the acute phase of the viral disease: measles ( $97 \%$ ), varicella (100\%), mumps (95\%), and echo-30 meningitis (99\%) with mean titres of $82.4,80.5,60.2$, $75 \cdot 2$, and $101 \cdot 1 \mu \mathrm{g} / \mathrm{ml}$ respectively. This increase in SAA was followed by a rapid return to normal concentrations $(<5 \mu \mathrm{g} / \mathrm{ml})$ during convalescence. Remarkably higher concentrations of SAA (mean $1630 \mu \mathrm{g} / \mathrm{ml}$ ) were detected in the acute phase of patients with Kawasaki disease, but in most of the children with chronic hepatitis $B$ or $C$, the titres of SAA remained normal. There was no close correlation between SAA and serum concentrations for $\alpha_{1}$-acid glycoprotein, $\beta_{2}$ microglobulin, transferrin, and IgG.

There was a clear correlation between SAA and $C$ reactive protein concentrations, although SAA showed a greater incremental change than $C$ reactive protein in the acute phase. In the acute phase of these viral diseases, $56 \%$ of the patients had raised SAA concentrations ( $\geqslant 5 \mu \mathrm{g} / \mathrm{ml}$ ) with normal C reactive protein concentrations $(<5 \mu \mathrm{g} / \mathrm{ml})$. These results indicate that SAA could be useful as an inflammatory marker in children with acute viral infections.

\section{(Arch Dis Child 1993;68:210-4)}

Serum amyloid A protein (SAA), a putative serum precursor of the amyloid $A$ protein that constitutes amyloid fibrils in secondary amyloidosis, ${ }^{1}$ has been clinically evaluated as one of the sensitive acute phase reactants in serum. ${ }^{2}$ For a decade increased concentrations of SAA have been reported in a number of inflammatory diseases. ${ }^{3-14}$ It has been particularly useful in the diagnosis of acute renal or hepatic allograft rejections ${ }^{15} 16$ and in monitoring disease activity in rheumatoid arthritis patients. ${ }^{17}$

In patients with bacterial infections, $C$ reactive protein has been widely recognised as a useful inflammatory marker, although no such markers have been identified for viral diseases. Viral infections have been reported to cause weak $C$ reactive protein responses, ${ }^{18}{ }^{19}$ and increased $C$ reactive protein concentrations have been used to distinguish bacterial from viral origins. In this study we investigated the clinical significance of SAA in viral diseases based on the following points: (1) kinetics of SAA in acute viral diseases, (2) comparisons of SAA between the acute and chronic viral diseases, (3) relation between SAA and $C$ reactive protein, (4) relation between SAA and other acute phase reactants.

We used the latex agglutination nephelometric immunoassay to assay SAA as it is simple, fast, and precise. ${ }^{20} \mathrm{We}$ also measured SAA in patients with Kawasaki disease, which is classified as a collagen vascular disease.

\section{Patients and methods}

PATIENTS

The study group consisted of 254 children with viral infections including measles $(n=34)$, varicella $(n=17)$, rubella $(n=31)$, mumps $(\mathbf{n}=37)$, enterovirus infections (echo-30 meningitis, $n=76)$, chronic hepatitis $B(n=29)$, and chronic hepatitis $C(n=30)$, and eight children with Kawasaki disease. The children were between 1 and 14 years old (mean 6.4 years). Measles, varicella, rubella, and mumps were diagnosed according to clinical findings and serological evaluations. Echo-30 meningitis was diagnosed based on clinical manifestations (fever, headache, vomiting, and stiff neck) and by lymphocytic pleocytosis of $>30 \times 10^{6}$ cells $/ 1$ in the cerebrospinal fluid. Isolation of the echo30 virus and/or serological examination by neutralising test were also conducted to confirm the diagnosis. Serum samples were collected during an epidemic in the Nagoya area in 1991.

Chronic hepatitis was defined as a continuous hepatic inflammatory process lasting one year or more. Patients with mild increases in serum aminotransferase activities (50-100 IU/l) were selected for study. Hepatitis $\mathrm{C}$ was diagnosed by detection of the C-100 antibody and by the presence of hepatitis C virus RNA using the polymerase chain reaction method. ${ }^{21} \mathrm{~A}$ diagnosis of hepatitis B was based on positive hepatitis B surface antigenaemia and presence of antihepatitis B core antibody. The diagnosis of Kawasaki disease was based on clinical manifestations and laboratory data. ${ }^{22}$

Sera were obtained from patients at designated intervals and stored at $-70^{\circ} \mathrm{C}$ until analysis. Single serum samples were also obtained from 51 age matched healthy children. 
SAA ASSAY: LATEX AGGLUTINATION NEPHELOMETRIC IMMUNOASSAY

SAA was measured by latex agglutination nephelometric immunoassay as described previously. ${ }^{20}$ SAA was purified from the pooled sera of patients with rheumatic arthritis. ${ }^{23}$ Antiserum to SAA was raised in rabbits according to standardised procedures. Immunoglobulin $G$ was isolated from the antiserum by diethylaminoethanol cellulose ion exchange chromatography, adjusted to $1 \mathrm{mg} / \mathrm{ml}$, and then conjugated to $10 \%$ polystyrene latex particles (mean diameter $0.1 \mu \mathrm{m}$ ) in $0.2 \mathrm{~mol} / 1$ ammonium buffer at $\mathrm{pH} 8.2$ for one hour at $37^{\circ} \mathrm{C}$. After washing, latex particles were suspended at $0.1 \%$ in the same ammonium buffer containing $0.5 \%$ bovine serum albumin. ${ }^{20}$ For the assay, an automated immunochemistry analyser, LX-3000 (Eiken Chemical Co Ltd and AIC, Tokyo, Japan), was used. An aliquot of $20 \mathrm{ml}$ of a test sample or assay standard, along with $240 \mu \mathrm{l}$ of $0.05 \mathrm{~mol} / 1$ hydroxyethylpiperazine-ethanesulphonic acid (HEPES) buffer at $\mathrm{pH} 7 \cdot 4$, and $80 \mu \mathrm{l}$ of a latex solution were mixed and incubated in glass cells at $37^{\circ} \mathrm{C}$. Light scattering was recorded at 45 seconds and 305 seconds after mixing, and any observed increases in this interval were used to calculate the SAA concentration. For the assay standard we used an SAA enriched high density lipoprotein. ${ }^{24}$

\section{ACUTE PHASE REACTANTS}

For other acute phase reactants we also measured $C$ reactive protein, $\beta_{2}$-microglobulin $\left(\beta_{2}-M\right)$, $\alpha_{1}$-acid glycoprotein $\left(\alpha_{1}-A G\right)$, transferrin, and IgG, in the same samples using the latex agglutination assay.

\section{Results}

SAA CONCENTRATIONS IN PATIENTS

Fifty one normal controls aged 1-14 years (mean 5.8) had mean (SD) SAA concentrations of $1.72(1.11) \mu \mathrm{g} / \mathrm{ml}$. From these data an arbitrary upper limit for the normal SAA concentration was set at $5.0 \mu \mathrm{g} / \mathrm{ml}$ (mean+ 3SD). In cases with acute viral diseases, SAA concentrations increased in the acute phase and declined thereafter throughout convalescence (see table 1). By contrast, however, in children with chronic hepatitis $B$ and $C$ the titre of SAA remained within normal at $3.0(2 \cdot 3) \mu \mathrm{g} / \mathrm{ml}$ in hepatitis $B$ and $1.5(1.1) \mu \mathrm{g} / \mathrm{ml}$ in hepatitis $C$ (fig 1).

\section{KINETICS OF SAA DURING THE COURSE OF ILLNESS}

Changes in the SAA concentration were investigated at designated intervals. Figure 2 shows the kinetics for SAA in 12 cases of measles, 14

Table 1 Mean $(S D)$ concentrations of $S A A(\mu g / m l)$ in the acute and convalescent phase of illness

\begin{tabular}{|c|c|c|c|c|c|c|}
\hline \multirow[t]{2}{*}{ Phase of illness } & \multicolumn{5}{|l|}{ Viral infection } & \multirow[b]{2}{*}{$\begin{array}{l}\text { Controls } \\
(n=5 I)\end{array}$} \\
\hline & $\begin{array}{l}\text { Measles } \\
(n=34)\end{array}$ & $\begin{array}{l}\text { Varicella } \\
(n=17)\end{array}$ & $\begin{array}{l}\text { Rubella } \\
(n=31)\end{array}$ & $\underset{(n=37)}{M u m p s}$ & $\begin{array}{l}\text { Echo-30 meningitis } \\
(n=76)\end{array}$ & \\
\hline $\begin{array}{l}\text { Acute } \\
\text { Convalescence }\end{array}$ & $\begin{array}{c}82 \cdot 4(113 \cdot 3) \\
4 \cdot 3(3 \cdot 3)\end{array}$ & $\begin{array}{c}80 \cdot 5(148 \cdot 9) \\
4 \cdot 3(2 \cdot 1)\end{array}$ & $\begin{array}{c}60 \cdot 2(71 \cdot 9) \\
3.0(2 \cdot 1)\end{array}$ & $\begin{array}{c}75 \cdot 2(160 \cdot 2) \\
3.0(2 \cdot 0)\end{array}$ & $\begin{array}{c}101 \cdot 1(157 \cdot 0) \\
3.4(1 \cdot 6)\end{array}$ & $1 \cdot 7(1 \cdot 1)$ \\
\hline
\end{tabular}

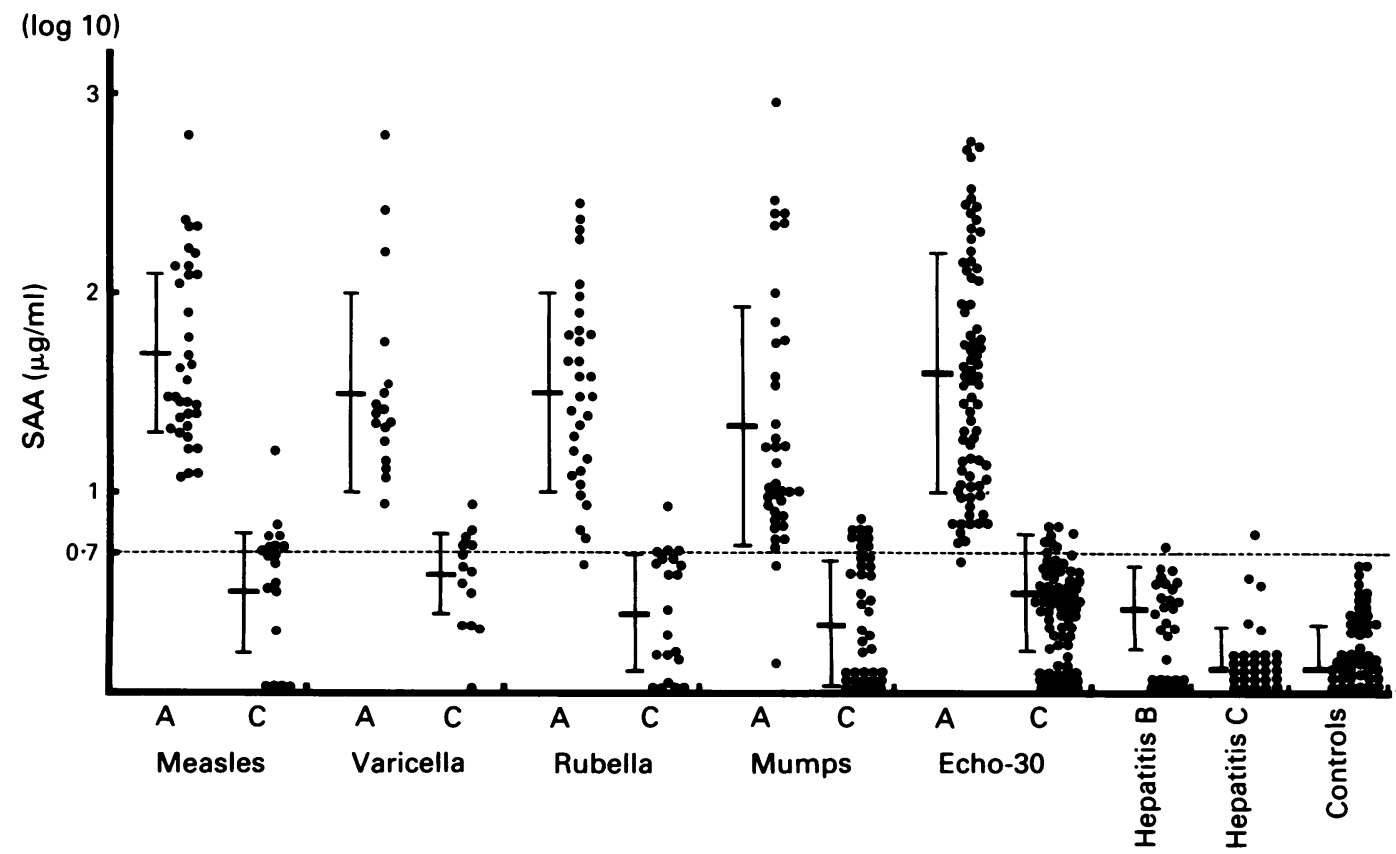

Figure 1 SAA concentrations in children with measles, rubella, varicella, mumps, echo-30 meningitis, hepatitis $B$, and hepatitis when compared with normal controls. SAA concentrations in serum samples from infected patients were obtained during the acute $(A)$ and convalescent $(C)$ phases of acute viral infections. The dotted line indicates the upper limit of the normal range. 

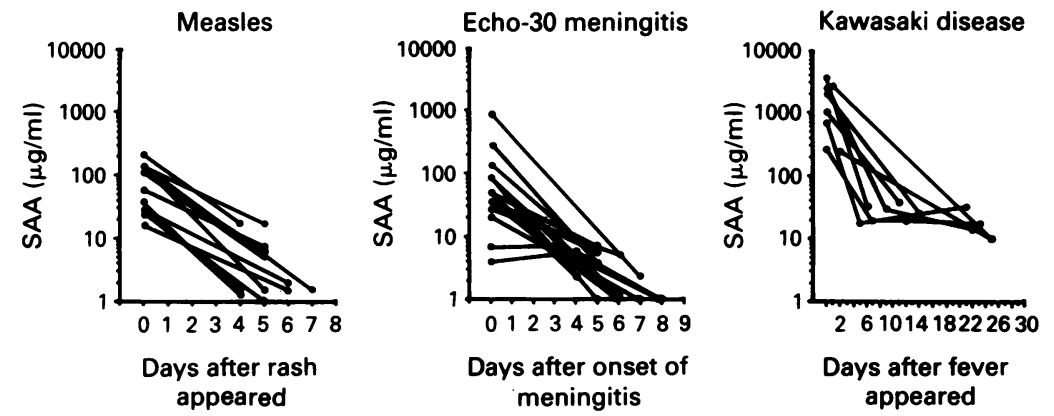

Figure 2 Kinetics for SAA concentrations in 12 children with measles, 14 with echo-30 meningitis, and eight with Kawasaki disease.
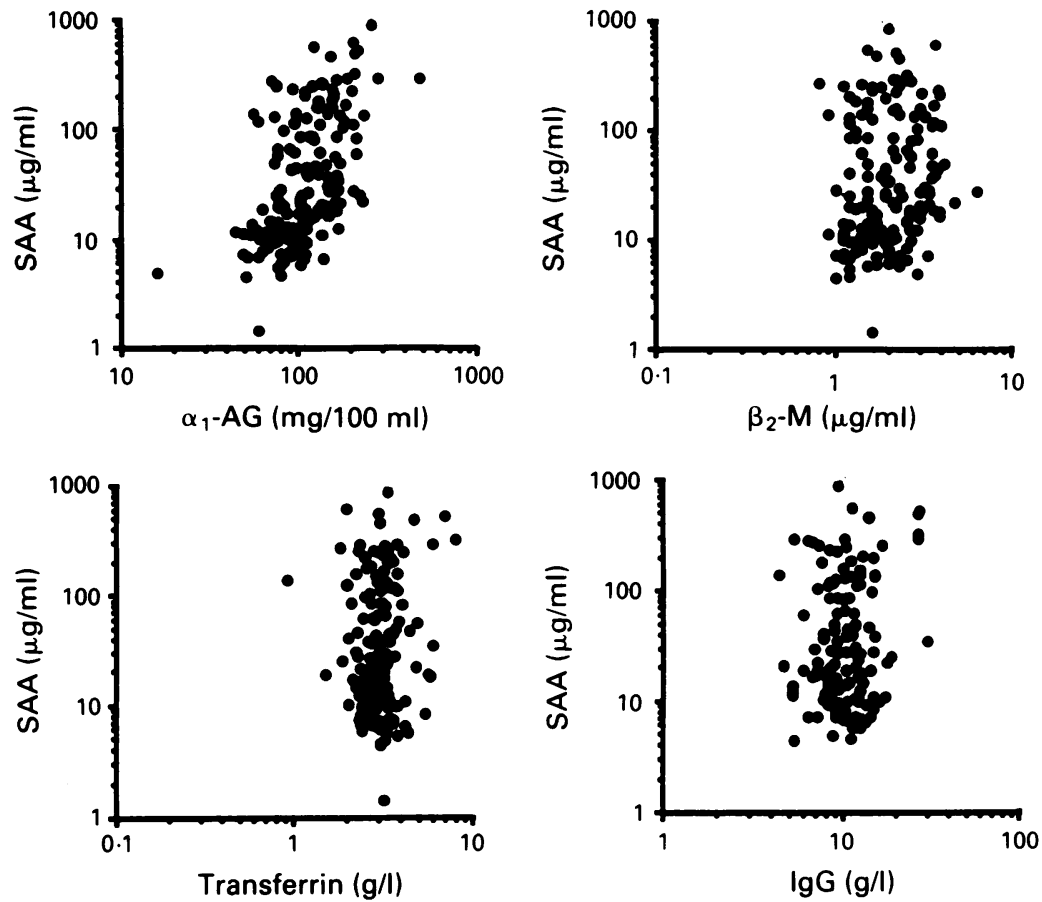

Figure 3 Relation between $S A A$ and other acute phase reactants $\left(\alpha_{1}-A G, \beta_{2}-M\right.$, transferrin and $I g G$ ) in sera during the acute phase of viral disease.
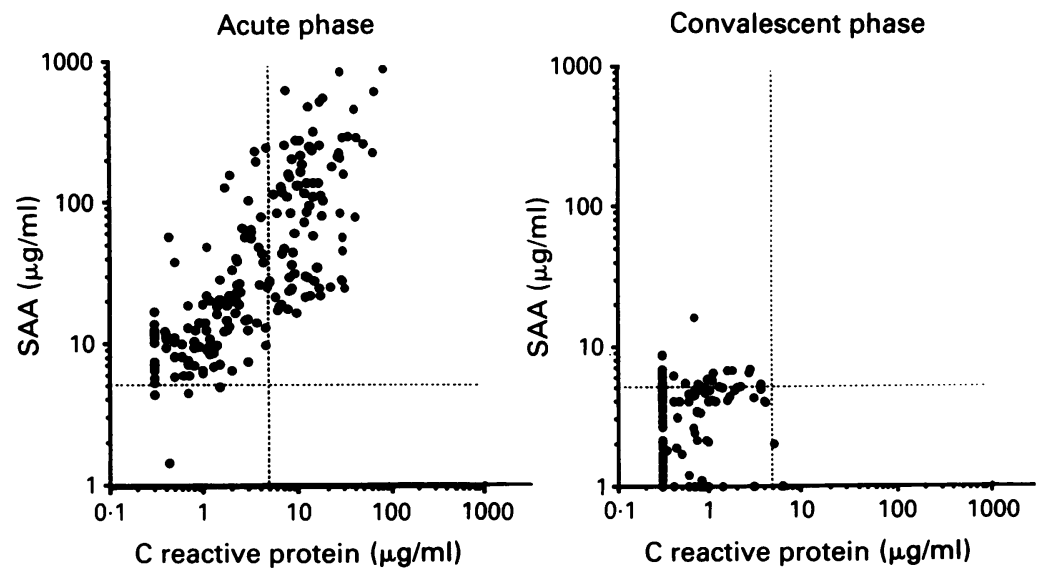

Figure 4 Relation between $S A A$ and $C$ reactive protein concentrations in children acute viral diseases. Dotted lines indicate the upper limit for the normal range.

Table $2 S A A$ and $C$ reactive protein in the acute and convalescent phase of illness. Figures are number (\%)

\begin{tabular}{|c|c|c|c|c|}
\hline & \multicolumn{2}{|c|}{ Acute $(n=195)^{*}$} & \multicolumn{2}{|c|}{ Convalescence $(n=165)^{*}$} \\
\hline & $S A A \geqslant 5$ & $S A A<5$ & $S A A \geqslant 5$ & $S A A<5$ \\
\hline $\begin{array}{l}C \text { reactive protein }(\mu \mathrm{g} / \mathrm{ml}) \text { : } \\
\geqslant 5 \\
<5\end{array}$ & $\begin{array}{r}81(41 \cdot 5) \\
110(56 \cdot 4)\end{array}$ & $\begin{array}{l}0 \\
4(2 \cdot 1)\end{array}$ & $\begin{array}{l}0 \\
35(21 \cdot 2)\end{array}$ & $\begin{array}{r}2(1 \cdot 2) \\
128(77 \cdot 6)\end{array}$ \\
\hline Total & $191(97 \cdot 9)$ & $4(2 \cdot 1)$ & $35(21 \cdot 2)$ & $130(78 \cdot 8)$ \\
\hline
\end{tabular}

${ }^{*}$ Number of patients with measles, varicella, rubella, mumps, and echo-30 meningitis. of echo-30 meningitis, and eight of Kawasaki disease. Higher than normal SAA was detectable in all patients with measles on the day the rash appeared, but SAA titres sharply declined between days 4 and 7 in seven of these cases and remained above normal in the remaining five cases. SAA concentrations were raised at the onset of neurological symptoms in 13 of the 14 patients with echo-30 meningitis. In nine of these cases, the SAA titre decreased dramatically between days 4 and 8 , but in the remaining five cases SAA concentrations continued to be high.

Remarkably higher titres in SAA were detectable in the acute phase of patients with Kawasaki disease, ranging from $250-3560 \mu \mathrm{g} / \mathrm{ml}$ (mean $1630 \mu \mathrm{g} / \mathrm{ml}$ ), and the concentrations remained at higher concentrations (from $10-50 \mu \mathrm{g} / \mathrm{ml}$ ) during convalescence.

\section{RELATION BETWEEN SAA AND ACUTE PHASE REACTANTS}

A comparison between SAA and acute phase reactants was conducted after preliminary findings that showed increases in SAA during the acute phase of viral infections. No close relations, however, could be found between the SAA concentration and serum concentrations for $\alpha_{1}-A G, \beta_{2}-M$, transferrin, or IgG (fig 3).

\section{RELATION BETWEEN SAA AND C REACTIVE} PROTEIN

A total of 195 children with acute viral infections were studied. In most of cases, acute phase proteins were measured on more than one occasion, resulting in 360 sets of measurements. A comparison of serum SAA and $C$ reactive protein concentrations is shown in fig 4 . A positive correlation $(r=0.86)$ was seen over a wide range of concentrations, both within and above normal. SAA, however, showed a greater incremental change in the acute phase with maximum concentrations ranging from 2-900 $\mu \mathrm{g} / \mathrm{ml}$ when compared with $\mathrm{C}$ reactive protein concentrations of $2-100 \mu \mathrm{g} / \mathrm{ml}$. It is interesting to note that increased SAA concentrations were observed despite normal $C$ reactive protein concentrations. Out of the 195 patients, 110 $(56.4 \%)$ showed increases in SAA during the acute phase, although the $\mathrm{C}$ reactive protein concentrations remained normal (table 2). No correlation could be found for this increased $\mathrm{SAA} /$ normal $\mathrm{C}$ reactive protein condition and the type of disease. In 130 out of 165 patients (79\%), SAA concentrations declined to within the normal range during convalescence, but remained above normal in the other $35(21 \%)$ patients. These results indicate that SAA may be useful as an inflammatory marker in cases with acute viral diseases.

\section{Discussion}

SAA has been clinically evaluated as an acute phase reactant sensitive to serum in a number of inflammatory diseases. It has been shown to be especially useful in the close monitoring of disease activity in rheumatoid arthritis patients. Increased SAA concentrations have been seen 
among serum samples taken from patients with viral diseases in the acute phase including cytomegalovirus, herpes simplex, rubella, measles, varicella, and herpes zoster. ${ }^{14}$ The significance of this phenomenon, however, has not yet been established, and SAA assaying has not been applied to a wide clinical use. One reason may be that the present methods for quantifying SAA, such as enzyme immunoassay, ${ }^{25} 27$ radioimmunoassay, 2627 and nephelometric immunoassay, ${ }^{28}$ are time consuming and unsuitable for application in clinical laboratories. For assaying SAA in this study we used the latex agglutination assay as it is simpler and faster than other methods that take more than an hour to complete. Accurate and rapid assessment of SAA values by this method could prove to be useful for evaluating acute viral diseases and thus should be included as a routine test in clinical applications. ${ }^{20}$

To establish the usefulness of SAA in evaluating viral diseases we reviewed a large series of children with measles, varicella, rubella, mumps, and echo-30 meningitis. Findings revealed an early rise in SAA concentrations $(98 \%)$ during the acute phase of viral diseases followed by a rapid return to normal concentrations $(79 \%)$ in convalescence. However, SAA concentrations in $35(21 \%)$ samples remained above normal even throughout convalescence. This may be due to the fact that most of these patients, especially those with measles and echo-30 meningitis, had not completely recovered from the disease by the time serum samples were obtained. These findings suggest that SAA could be useful as a marker of clinical recovery in patients with viral diseases. By contrast, we found that titres of SAA remained within normal ranges in patients with chronic hepatitis B and C.

Sera obtained from patients in the acute phase of viral disease showed no close correlation between SAA concentrations and serum concentrations for $\alpha_{1}-A G, \beta_{2}-M$, transferrin, and IgG. These findings are of considerable interest as they illustrate the discrepancies among different acute phase proteins in patients with viral infections.

A comparison of SAA and $C$ reactive protein concentrations revealed a correlation over a wide range both within and above normal. SAA, however, showed a greater incremental change in the acute phase of the disease when compared with $\mathrm{C}$ reactive protein. Moreover, raised SAA concentrations were observed despite normal $\mathrm{C}$ reactive protein concentrations, accounting for $56 \%$ of all acute phase samples, Unlike $\mathrm{C}$ reactive protein in bacterial infections, no reliable markers are available for monitoring viral diseases. Clinical signs and symptoms such as fever with no $\mathrm{C}$ reactive protein increase may suggest the presence of a viral infection. In our study more than half of the patients $(56 \%)$ had increased SAA $(\geqslant 5 \mu \mathrm{g} / \mathrm{ml})$ with no increases in $C$ reactive protein $(<5$ $\mu \mathrm{g} / \mathrm{ml}$ ) during the acute phase. These results indicate that the assay of SAA in combination with $C$ reactive protein could be useful to confirm a diagnosis of acute viral infection. Approximately $40 \%$ of our patients, however, demonstrated increases in both SAA and C reactive protein. This may be due to coexisting infections of a bacterial or other origin, although previous studies have suggested that $\mathrm{C}$ reactive protein concentrations increase in cases with severe viral infection alone. ${ }^{29}$

The mechanism by which inflammatory stimuli induce the synthesis of SAA in hepatocytes and other acute phase proteins has been a subject of intense investigation in recent years. Many studies indicate that interleukin(IL)-1, IL-6, and the tumour necrosis factor are mediators for modulating of liver synthesis in these acute phase proteins. ${ }^{30}$ Our findings suggest that cytokines synthesised in viral infections may be responsible for the increases in SAA, and that SAA synthesis in the hepatocyte may be more easily activated by IL-1 and IL- 6 than $C$ reactive protein or other acute phase proteins. During the silent stages of chronic hepatitis B and C, SAA concentrations do not show any such increases probably due to the weak stimuli by cytokines.

As far as we know this is the first report of acute phase responses of SAA in Kawasaki disease, which is classified as a collagen vasculitis with unknown aetiology. In this study the concentration of SAA in Kawasaki disease was extremely high in the acute phase but declined thereafter within several days. The concentrations of SAA, however, remained at higher values (from $10-50 \mu \mathrm{g} / \mathrm{ml}$ ) during convalescence. Monitoring SAA, therefore, may be useful as marker for disease activity and responses to treatment in Kawasaki disease.

In conclusion, an increase in SAA concentration may provide a useful marker of viral infection in cases where a differential diagnosis may be difficult clinically and where viral isolation may not be possible.

1 Husby G, Natvig JB. A serum component related to nonimmunoglobulin amyloid protein AS, a possible precursor immunoglobulin amyloid protein AS, a possib
of the fibrils. $\mathcal{F}$ Clin Invest 1974;53:1054-61.

2 Kushner I, Gewurz H, Benson ML. C-reactive protein and the acute-phase response. F Lab Clin Med 1981;97:739-49.

3 Raynes JG, Coopper EH. Comparison of serum amyloid $A$ protein and C-reactive protein concentrations in cancer and non-malignant disease. 7 Clin Pathol 1983;36:798-803.

4 Whiches JT, Chambers RE, Higginson J, Nashef L, Higgins PG. Acute phase response of serum amyloid A protein and $\mathrm{CG}$. Acute phase response or serum amyloid A protein and Pathol 1985:38:312-6.

5 Rosenthal CJ, Franklin EC. Variation with age and disease of an amyloid A protein related serum component. $\mathcal{J}$ Clin Invest 1975;55:746-53.

6 Gorevic PD, Rosenthal CJ, Franklin EC. Amyloid related serum component (SAA) studies in acute infections, medullary thyroid carcinoma and post surgery. Clin Immunol Immunopathol 1976;6:83-93.

7 McAdam KPWJ, Elin RJ, Sipe JD, Wolff SM. Changes in human serum amyloid $A$ and $C$-reactive protein after etiocholanolone-induced inflammation. $\mathcal{F}$ Clin Invest 1978; 61:390-4.

8 Rosenthal CJ, Sullivan LM. Serum amyloid A to monitor cancer dissemination. Ann Intern Med 1979;91:383-90.

9 Rosenthal CJ, Noguera C, Platica O, Sullivan L. Serum amyloid $A$ : monitor to cancer dissemination. In: Glenner GC, Costa PP, Falco de Freitas, eds. Amyloid and amyloidosis. Amsterdam: Excerpta Medica, 1980:43-9.

10 Benson MD, Cohen AS. Serum amyloid A protein in amyloidosis, rheumatic and neoplastic diseases. Arthritis Rheum 1979;22:36-42.

11 Maury CPJ, Teppo AM, Wegalius O. Relationships between urinary sialylated saccharides, serum amyloid $A$ and $\mathrm{C}$-reactive protein in rheumatoid arthritis and systemic lupus erythematosus. Ann Rheum Dis 1982;412:268-71.

12 De Beer FC, Mallya RK, Fagan EA, Lanham JG, Hughes GRV, Pepys MB. Serum amyloid A protein concentration in inflammatory diseases and its relationship to the incidence of reactive systemic amyloidosis. Lancet 1982;i:231-3.

13 Marhaug G, Permin H, Hushy G. Amyloid-related serum 
protein (SAA) as an indicator of lung infection in cysticfibrosis. Acta Paediatr Scand 1983;72:861-6.

14 Shainkin-Kestenbaum R, Zimlichman S, Winikoff Y, Pras M Chaimovits C, Sarov I. Serum amyloid A (SAA) in vira infection: rubella, measles and subacute sclerosing panencephalitis (SSPE). Clin Exp Immunol 1982;50:503-6.

15 Maury CPJ, Teppo AM, Eklund B, Ahonen I. Serum amyloid A protein: a sensitive indicator of renal allograft amyloid A protein: a sensitive indicator of re

16 Maury CPJ, Hockerstedt K, Lautenschlager I, Scheinin TM Monitoring of high density lipoprotein-associated amyloid A protein after liver transplantation. Transplant Proc 1987; XIX:3825-6.

17 Chambers RE, Macfarlane DG, Whicher JT, Dieppe PA. Serum amyloid-A protein concentration in rheumatoid arthritis and its role in monitoring disease activity. Ann Rheum Dis 1983;42:665-7.

18 McCarthy PL, Frank AL, Ablow RC, Masters SJ, Dolan TF. Value of $\mathrm{C}$-reactive protein test in the differentiation of bacterial and viral pneumonia. $\mathcal{A}$ Pediatr 1978;92:454-6.

19 Saxstad J, Nilsson LA, Hanson LA. C-reactive protein in serum from infants as determined with immuno diffusion serum from infants as determined with immuno diffusion techniques. II. Infants

20 Yamada T, Nomata Y, Sugita O, Okada M. A rapid method of measuring serum amyloid $A$ protein by latex agglutination nephelometric immunoassay. Ann Clin Biochem (in press).

21 Shibata M, Morishima T, Kudo T, Maki T, Maki S, Nagai Y Serum hepatitis $C$ virus sequences in posttransfusion non-A, non-B hepatitis. Blood 1991;77:1157-60.

22 Schaller JG, Wedowood RJ, Kawasaki disease (mucocutaneous lymph node syndrome). In: Behrman RE,
Vaughan VC III, eds. Nelson textbook of pediatrics. 13th Ed. Philadelphia: WB Saunders, 1987:529.

23 Marhang G, Husby G. Characterization of human amyloidrelated protein SAA as a polymorphic protein; association
with albumin and prealbumin in serum. Clin Exp Immunol with albumin and

24 Godenir NL, Jeenah MS, Coetzee GA, Van der Westhuyzen DR, Stachan AF, De Beer FC. Standardization of the quantitation of serum amyloid A protein (SAA) in human serum. F Immunol Methods 1985;83:217-25.

25 Yamada T, Uchiyama K, Yakata M, Gejyo F. Sandwich enzyme immunoassay for serum amyloid A protein (SAA). Clin Chim Acta 1989;179:169-76.

26 Benson MD, Cohen AS. Serum amyloid A protein in amyloidosis, rheumatic and neoplastic diseases. Arthritis Rheum 1979;22:36-42.

27 Marhaug G. Three assays for the characterization and quantitation of human serum amyloid. Scand 7 Immunol 1983;18: 329-38.

28 Hocke G, Ebel H, Bittner $\mathbf{K}$, Miller T, Kaffarnik H, Steinmetz A. A rapid laser immunonephelometric assay for serum amyloid A (SAA) and its application to the diagnosis of kidney allograft rejection. Klin Wochenschr 1989;67: of kidney

29 Salonen EM, Vaheri A. C-reactive protein in acute viral infections. F Med Virol 1981;8:161-7.

30 Yap SH, Moshage HJ, Hazenberg BPC, et al. Tumor necrosis factor (TNF) inhibits interleukin (IL) -1 and/or IL-6 stimulated synthesis of $\mathrm{C}$-reactive protein (CRP) and serum amyloid A (SAA) in primary cultures of human hepatocytes. Biochim Biophys Acta 1991;1091:405-8. 